\title{
SOIL CHISELING AND FERTILIZER LOCATION IN SUGARCANE RATOON CULTIVATION
}

\section{ALOISIO BIANCHINI ${ }^{1}$, DANIEL D. VALADÃO JUNIOR ${ }^{2}$, RODRIGO P. ROSA $^{3}$, FREDERICK COLHADO ${ }^{4}$, RODRIGO F. DAROS ${ }^{4}$}

\begin{abstract}
While the pre-harvest sugarcane burning is a disused practice, green harvest requires changes concerning ratoon cultivation due to the presence of a thick layer of straw. The experiment, conducted in a mechanical green harvesting area cultivated with sugarcane, consisted of two stages: in the first stage, the mechanical straw cutting performance of flat disks with different geometry edges was evaluated, considering two types of disks and 10 replications in a completely randomized design; in the second stage, the effect of soil chiseling on both sides of planting lines, using shanks with straw cutting flat disks, was assessed, as well as fertilizer deposition form. The experimental design in the second stage was completely randomized, with seven treatments and five replications. Treatments consisted of a combination of two straw cutting disks (smooth or toothed edge), chiseling presence or absence, and fertilizer deposition forms (broadcast, on the planting line, and incorporated into chiseling furrows). The toothed disk differed from the smooth one, presenting lower values of horizontal and vertical forces, and torque. The agroindustrial variables pol (\%), brix (\%), fiber (\%), and ATR ( $\left.\mathrm{kg} \mathrm{Mg}^{-1}\right)$ were not influenced by the fertilizer deposition form and soil chiseling. However, the localized fertilizer deposition increased crop yield when compared with broadcast fertilization.
\end{abstract}

KEYWORDS: Saccharum officinarum, cutting disk, mulching.

\section{ESCARIFICAÇÃO DO SOLO E LOCALIZAÇÃO DO FERTILIZANTE NO CULTIVO DA SOQUEIRA DE CANA-DE-AÇÚCAR}

RESUMO: A colheita da cana-de-açúcar com queima é prática em desuso, e a de cana crua está exigindo mudanças na forma de cultivo da soqueira devido à presença da espessa camada de palha. $\mathrm{O}$ experimento, desenvolvido em área de colheita mecanizada de cana-de-açúcar sem queima, constou de duas etapas: na primeira, avaliou-se o desempenho mecânico de discos planos de corte de palha com geometria de bordas diferentes, considerando dois modelos de discos e 10 repetições sob delineamento inteiramente casualizado. A segunda etapa do experimento teve como objetivo avaliar o efeito da escarificação do solo em ambos os lados das fileiras de plantas, por meio de hastes, munidas de discos planos de corte de palha e da forma de deposição do fertilizante. $\mathrm{O}$ delineamento experimental adotado na segunda etapa foi o inteiramente casualizado, com sete tratamentos e cinco repetições. Os tratamentos foram compostos da combinação dos dois modelos diferentes de discos para corte da palha (borda lisa ou dentada), presença ou ausência de escarificação e formas de deposição de fertilizante (a lanço, sobre a fileira e incorporado no sulco de escarificação). Os valores das forças horizontal, vertical e do torque exigidos pelo disco de corte de palha dentado foram inferiores ao do disco liso. As variáveis agroindustriais pol (\%), ${ }^{\circ}$ brix (\%), fibra (\%) e ATR $\left(\mathrm{kg} \mathrm{Mg}^{-1}\right)$ não foram influenciadas pela forma de deposição do fertilizante e escarificação. No entanto, a deposição do fertilizante de forma localizada proporcionou incremento na produtividade de colmos de cana e no rendimento de açúcar, em relação à fertilização a lanço.

PALAVRAS-CHAVE: Saccharum officinarum, disco de corte, palha.

\footnotetext{
${ }^{1}$ Prof. Associado Depto. de Solos e Engenharia Rural, Faculdade de Agronomia, Veterinária e Zootecnia, UFMT, bianchi@ufmt.br.

${ }^{2}$ Prof. Doutor Instituto Federal de Mato Grosso, Campus de Campo Novo do Parecis.

${ }^{3}$ Aluno do Programa de Pós-graduação em Agricultura Tropical. Faculdade de Agronomia, Veterinária e Zootecnia, UFMT.

${ }^{4}$ Aluno de iniciação científica do curso de Graduação em Agronomia. Faculdade de Agronomia, Veterinária e Zootecnia, UFMT.

Recebido pelo Conselho Editorial em: 19-6-2012

Aprovado pelo Conselho Editorial em: 3-9-2013
} 


\section{INTRODUCTION}

Pre-harvest sugarcane burning has been widely used in all Brazilian sugarcane regions; however, due to environmental concerns such as emission of greenhouse gases, there is a strong social pressure for the extinction of this practice by the sugar industry (PERES et al., 2010). As an alternative, the green harvest system arises using automotive harvesting machines (RODRIGUES \& ABI SAAB, 2007), so leaves, sheathes, tips, and variable amounts of culm pieces are cut and deposited on soil surface, generating a thick layer of plant residue.

One of the main practical implications of the sugarcane green harvest is the need to change the management of sugarcane fields, mainly regarding ratoon cultivation, which includes soil chiseling and fertilization. After mechanical harvest, chiseling and deposition of fertilizer incorporated into the soil are difficult because of presence of great straw amounts on soil surface and, also, inefficiency of commercially available straw cutting disks. According to BIANCHINI (2008), under conditions of low soil moisture, the machine weight is not enough to produce straw cutting disk penetration; under conditions of high soil moisture close to field capacity, disks push the straw either into the soil or forward, what causes frequent machine plugging. This same problem also occurs for other crops as mentioned by ARATANI et al. (2006), who state that the main No Tillage demotivating factor, in the Paranapanema region of São Paulo State, is the difficult soybean sowing on great straw amounts derived from the previous cultivation of winter maize. Other study, presented by SILVA et al. (2012), who worked with smooth, corrugated, and wavy disks, demonstrated that performance, and vertical and horizontal forces, are influenced by the format of straw cutting disks of drill seeders.

According to RAMÃO et al. (2007), the sugarcane harvest mechanization represents a deepened innovation process of the sugarcane industry, promoting an intensification of the agroindustrial production and reducing costs. However, such harvest process may cause an additional soil compaction (SEVERIANO et al., 2010) with lower infiltration rates (TOMASINI et al., 2010), what indicates changes to soil porosity. CARVALHO et al. (2011) verified an increased bulk density, in a sugarcane area, associated with a possible subsurface compaction due to heavy traffic at harvest time and, also, absence of soil mechanical mobilization. These reports indicate that, for sugarcane ratoon cultivation, it is necessary to look into the soil physical characteristics to understand the need for chiseling. However, for chiseling application in the ratoon cultivation process after green harvest, it is necessary to use machines that allow fertilization and chiseling of sugarcane crops with minimal straw movement.

The straw layer does influence ratoon cultivation operations hampering fertilizer incorporation, what has been modifying the nitrogen sources used for sugarcane ratoon fertilization (OTTO, 2012). This author also states that, nowadays, there have been inquires about the best nitrogen fertilizer source for areas of green harvest as well as about the best fertilizer application form. Considering costs of nitrogen fertilizers, it is essential to develop an appropriate nitrogen fertilization management in order to aim at the better $\mathrm{N}$ use by sugarcane crops (FRANCO et al., 2008).

In this sense, the objective of this study was to evaluate, in an area of sugarcane mechanical green harvest, the performance of straw cutting disks associated with soil chiseling and fertilizer deposition forms.

\section{MATERIAL AND METHODS}

The study was conducted in an area belonging to the Itamarati Mill, located in Nova Olímpia, Southwestern Mato Grosso State, Brazil, which slope was considered slightly undulated. Local climate regime, according to the Köppen classification, is Aw type - hot and humid, with a mean temperature of $25^{\circ} \mathrm{C}$. Annual rainfall ranges from 1,750 to $1,800 \mathrm{~mm}$, concentrated from December to March. Soil in the experimental area is classified as an Oxisol of loam texture $\left(0.720 \mathrm{~kg} \mathrm{dm}^{-3}\right.$ sand, $0.027 \mathrm{~kg} \mathrm{dm}^{-3}$ silt, and $0.252 \mathrm{~kg} \mathrm{dm}^{-3}$ clay). The chosen area, cultivated with the RB86-7515 
variety and mechanically green harvested, represented a commercially sugarcane crop in its third regrowth. Straw amount on soil surface was dense, with $17.69 \mathrm{Mg} \mathrm{ha}^{-1}$ dry mass, $74 \mathrm{~mm}$ height, and 75.5 g.kg ${ }^{-1}$ water content. Soil water content was $152.9 \mathrm{~g} \mathrm{~kg}^{-1}$.

Evaluation of soil compaction was performed using an electronic penetrometer of constant speed. Values obtained from 20 surveys in the experimental area generated the mean behavior of soil penetration resistance (SPR). The result of this analysis is presented in Figure 1, where it is observed that SRP values, between 50 and $300 \mathrm{~mm}$ depths, are close to $2.2 \mathrm{MPa}$.

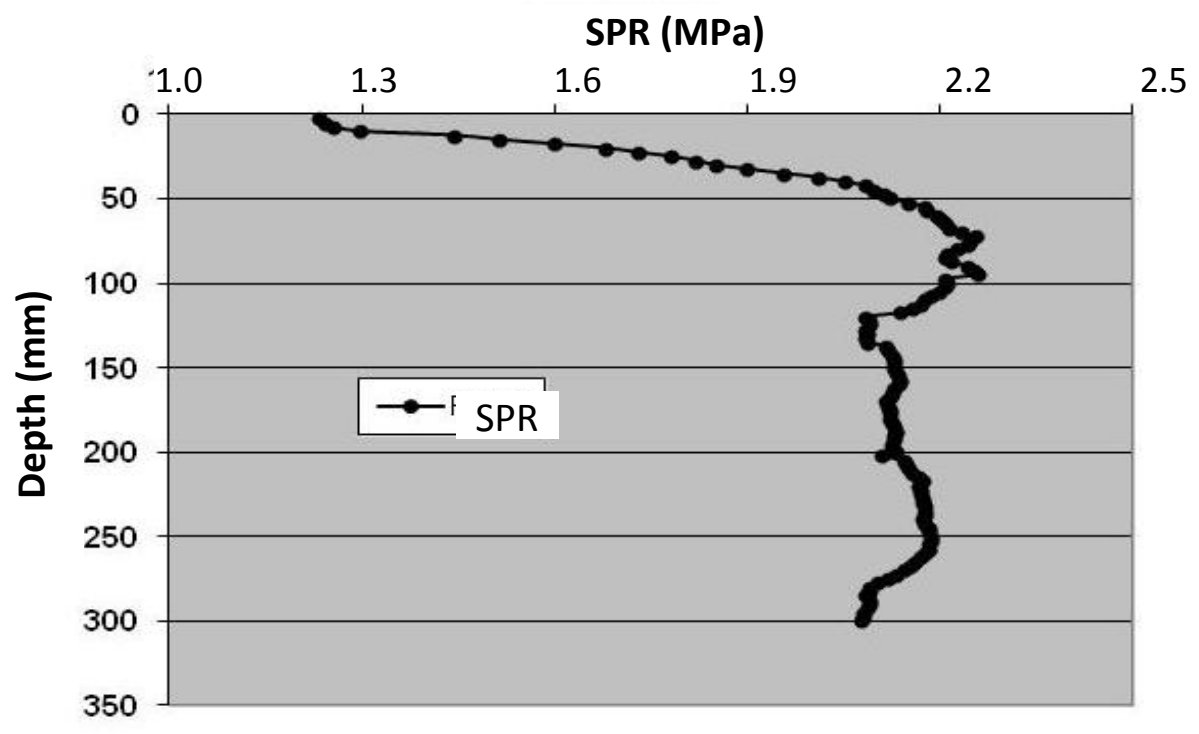

FIGURE 1. Mean soil penetration resistance (SPR) of 20 surveys performed in the experimental area.

The experiment was divided into two stages. Firstly, the mechanical performance of two straw cutting flat disks with different geometry edges was evaluated. One of the disks, of 26 " commercial standard $(660.4 \mathrm{~mm})$, had smooth edges; the other, with toothed edges and same diameter, was made from the smooth one, according to Figure 2 A.

Mechanical performance of the straw cutting flat disks was evaluated considering a completely randomized design, with two treatments and 10 replications. Data collection was carried out with the help of an equipment called tool holder car, which had an octagonal ring (Figure 2 B) and system for data acquisition connected to a notebook for data acquisition and storage system management during evaluations. Using the octagonal ring, vertical and horizontal forces as well as the torque demanded by the disk, were determined at $80 \mathrm{~mm}$ depth.
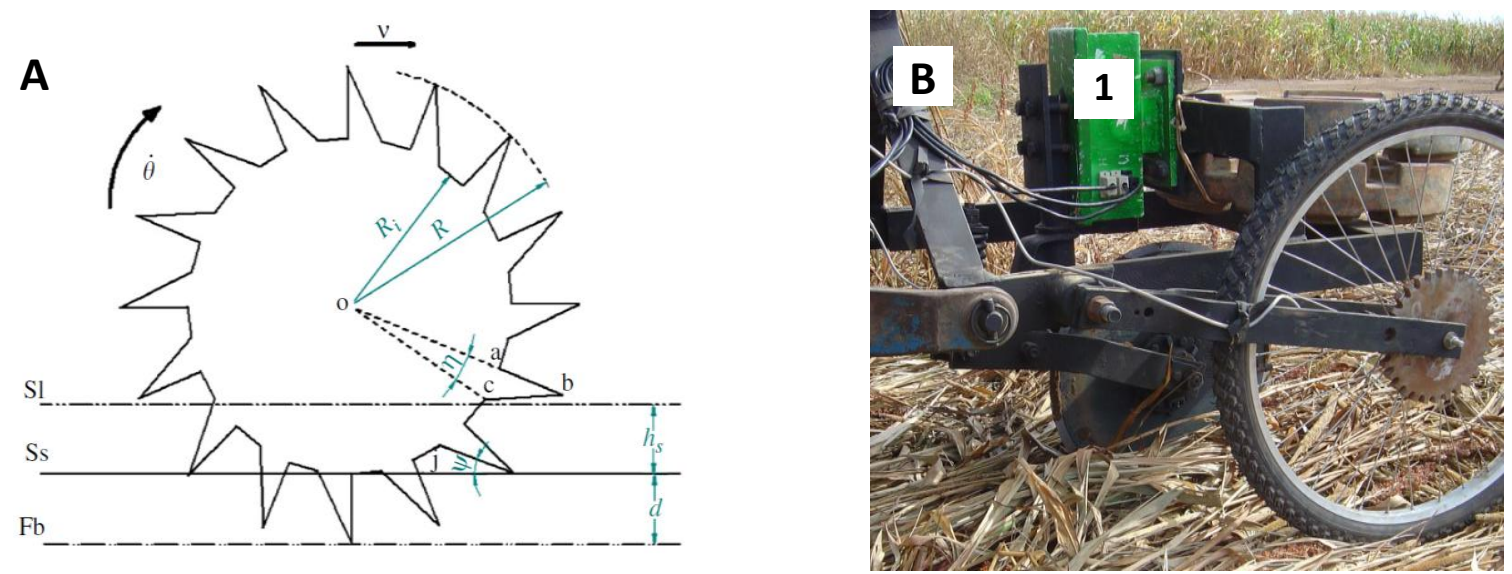

FIGURE 2. A: Geometry of the straw cutting toothed disk (Source: MAGALHÃES et al. 2007); B: Tool holder car with smooth disk and octagonal ring (1). 
The second experimental stage consisted of the evaluation of sugarcane ratoon cultivation, considering fertilizer location, and chiseling presence or absence. The experimental design was completely randomized, with seven treatments and five replications. Treatments are described as follows:

- Ch.TD-PL - Soil chiseling with shanks, straw cutting with flat toothed disk, and fertilizer deposition on planting lines.

- Ch.TD-If - Soil chiseling with shanks, straw cutting with flat toothed disk, and fertilizer incorporation into chiseling furrows.

- Ch.SD-PL - Soil chiseling with shanks, straw cutting with flat smooth disk, and fertilizer deposition on planting lines.

- Ch.SD-If - Soil chiseling with shanks, straw cutting with flat smooth disk, and fertilizer incorporation into chiseling furrows.

- ChA.DA-PL - Chiseling absence and fertilizer deposition on planting lines.

- ChA.DA-TA - Chiseling absence and total area fertilizer deposition (Mill's standard).

- Control - Chiseling and fertilization absence.

Treatments were arranged in lines and each experimental plot was composed of six 10 planting lines, of $10 \mathrm{~m}$ length each, considering only the four inner lines as the useful area. For plot separation, plants on the boundary line were removed each $3 \mathrm{~m}$ intervals, with herbicide. For treatment implementation, that is, localized ratoon fertilization and soil chiseling, a cultivatorfertilizer machine was used, with two ranks and two chiseling shanks for each planting line (Semeato Agricultural Machinery, CS2 model). Each chiseling shank had a straw cutting disk of 26 " diameter, with either smooth or toothed edges, according to the treatment (Figure 3). The curved chiseling shanks reached $0.15 \mathrm{~m}$ depth and the fertilizer, when incorporated, was deposited on the furrow bottom, i.e., at $0.15 \mathrm{~m}$ depth. The applied fertilizer dose was $558 \mathrm{~kg} \mathrm{ha}^{-1}$ of NPK 2200-20, what corresponds to the Mill's standard dosage. For the broadcast fertilization treatment, a double disk inertial distributor was used. In order to avoid contamination of the other plots, those that received broadcast fertilization had a $15 \mathrm{~m}$ border.
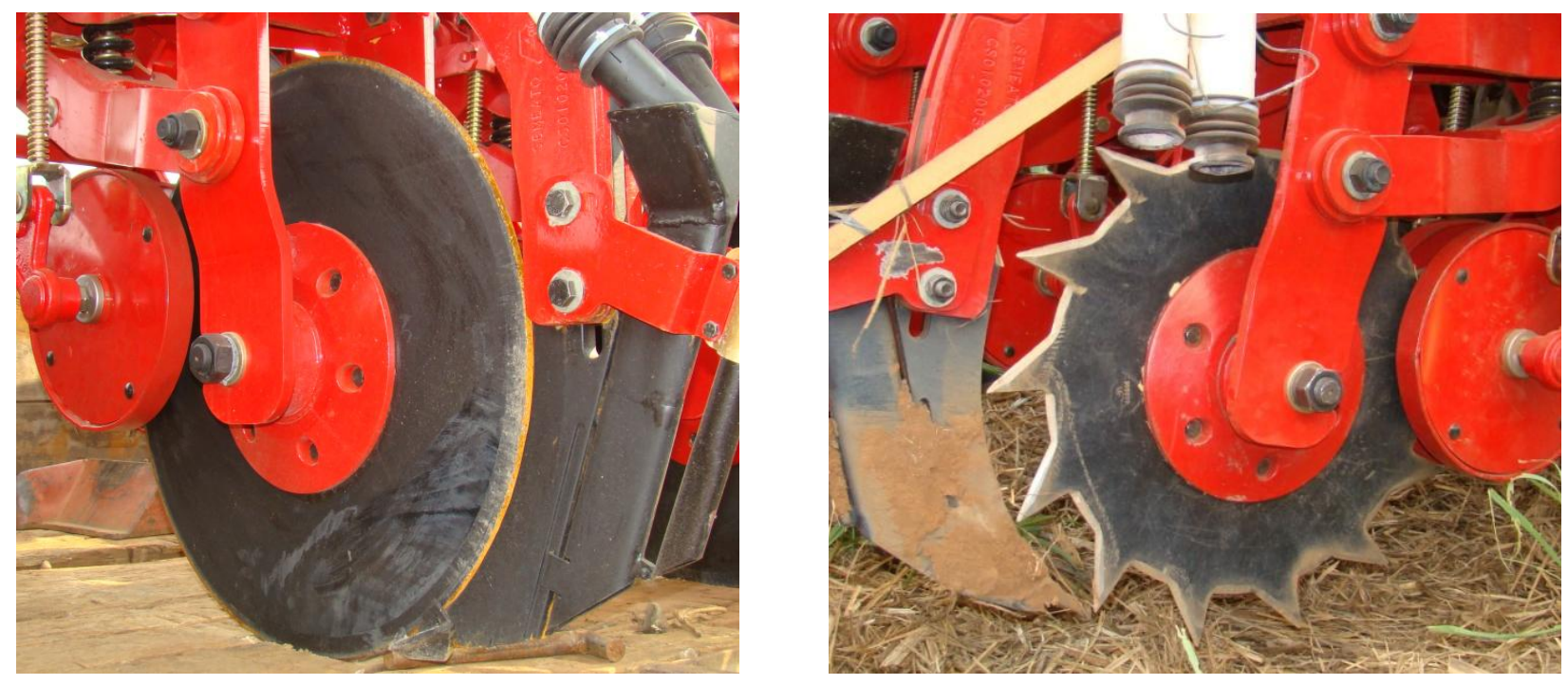

FIGURE 3. Aspect of the cultivator with a chiseling shank, smooth disk (left), and toothed disk (right).

\section{RESULTS AND DISCUSSION}

Results from the first experiment, when both horizontal and vertical forces were evaluated, as well as torque, in the disk axis, are shown in Table 1. Superior values are observed for the smooth disk, in comparison with the toothed one, for all studied variables. Results obtained by BIANCHINI 
\& MAGALHÃES (2008), who worked with sugarcane straw comparing toothed, indented, and smooth disks under laboratory conditions (chamber and soil), were similar to those found for this study. The toothed disk studied by those authors also presented lower values for torque, and horizontal and vertical forces.

The vertical force is necessary so that the cutting disk is able to penetrate the soil; it is directly related to sharpening degree, disk edge format (edge geometry), and disk thickness and diameter (BIANCHINI and MAGALHÃES, 2008). The tested disks had the same diameter and thickness, and were equally sharpened, so the differences found for vertical forces from smooth and toothed disks refer, exclusively, to the edge geometry.

TABLE 1. Vertical (VF) and horizontal (HF) forces, torque $\left(\mathrm{M}_{\mathrm{c}}\right)$, required Power $(\operatorname{Pr})$, and demanded energy (De) per cutting disk, obtained in the evaluation of smooth and toothed disks.

\begin{tabular}{lllllc}
\hline \multirow{2}{*}{ Disk Model } & \multicolumn{5}{c}{ Variables } \\
\cline { 2 - 6 } & $\mathrm{VF}(\mathrm{kN})$ & $\mathrm{HF}(\mathrm{kN})$ & $\mathrm{M}_{\mathrm{c}}(\mathrm{Nm})$ & $\operatorname{Pr}(\mathrm{kW})$ & De $\left(\mathrm{kWh} \mathrm{ha}^{-1}\right)^{*}$ \\
\hline Toothed & $1.74 \mathrm{a}$ & $0.54 \mathrm{a}$ & $72 \mathrm{a}$ & $1.69 \mathrm{a}$ & $3.14 \mathrm{a}$ \\
Smooth & $3.12 \mathrm{~b}$ & $0.98 \mathrm{~b}$ & $212 \mathrm{~b}$ & $0.93 \mathrm{~b}$ & $1.73 \mathrm{~b}$ \\
\hline
\end{tabular}

*Energy demand calculated for one planting line (two disks). Values followed by the same letter in the column do not differ from each other by the Tukey test at 0.05 probability level.

The necessary vertical force for a $660.4 \mathrm{~mm}$ (26") smooth disk penetrate the soil was $3.12 \mathrm{kN}$, a superior value to that obtained for the horizontal force, $0.98 \mathrm{kN}$, which is required for disk movement and rotation (Table 1). MION \& BENEZ (2008), who also worked with smooth disks of $381 \mathrm{~mm}$ diameter (15"), reached a mean vertical force of $1.24 \mathrm{kN}$. However, CHOI \& ERBACH (1986) found the mean vertical force of $1.06 \mathrm{kN}$ for disks of $410 \mathrm{~mm}$ (16") and $480 \mathrm{~mm}$ (18"). The required vertical force by straw cutting disks is proportional to their diameter; therefore, disks of greater diameter demand major vertical force for soil penetration. This occurs because they have larger contact area. However, the disk edge geometry may alter that proportion as it happened with the toothed disk, which required a minor vertical force than the smooth one. Vertical force values obtained in this study for the 26 " toothed disk were similar to those found by MION \& BENEZ (2008) for smooth disks of 15 " diameter, i.e., for 1.7 times smaller disks.

The advantage of working with disks of large diameters is that they present greater capacity for straw cutting as demonstrated by ARATANI et al. (2006). The disk tested by those authors, of $460 \mathrm{~mm}$ diameter (18"), required 23 pauses due to machine plugging in a 1,500 $\mathrm{m}$ route, while the $510 \mathrm{~mm}(20$ ") disk demanded only three pauses. However, the bigger the cutting disk is, the greater its vertical force requirement is for soil penetration and appropriate straw cutting. For increased disk vertical force, it is necessary to enhance machine weight that will act as a ballast to cancel the normal disk penetration reaction. Increased machine weight results in an increment in the traction forces required by the tractor not because of the horizontal force demanded by the disk, but because of the machine rolling resistance.

The horizontal force required by the cutting disk is that necessary force for traction; it is important because it influences the required power and, consequently, fuel consumption. The toothed disk tested in this study required a horizontal force of only $0.54 \mathrm{kN}$, while the smooth one demanded $0.98 \mathrm{kN}$ (Table 1). In any case, values obtained for both disks were lower than those found by MION \& BENEZ (2008), which required mean horizontal force was $1.304 \mathrm{kN}$ for a disk of $381 \mathrm{~mm}$ diameter (15"). CHOI \& ERBACH (1986) demonstrated that the horizontal force required by cutting disks of 410 and $460 \mathrm{~mm}$ (16" and 18", respectively) was affected by their diameter, reaching mean values of $0.321 \mathrm{kN}$. However, SANTOS et al. (2010) detected values around $4.5 \mathrm{kN}$ for smooth cutting disks of $508 \mathrm{~mm}$ diameter (20") used in a no tillage area, which 
are superior to values described by other authors. Apart from intrinsic disk characteristics, such as diameter, thickness, edge geometry, and sharpening degree, disk behavior is influenced by soil and straw conditions at cutting time.

The moment of the applied force in the cutting disk center is the necessary torque for rotation. The toothed disk demanded $72 \mathrm{Nm}$ torque, which is an inferior value to that required by the smooth one, $212 \mathrm{Nm}$. Disk capacity for straw cutting may be measured by torque because, under dynamic conditions, as lower the torque required by the disk is, as greater the cutting capacity of straw deposited on soil surface is. When the torque required by the disk is high, there is a possible disk slip, i.e., a forward movement without rotation. Under this condition, the cutting disk pushes the straw forward, which accumulates and may produce a collapsing process commonly known as plugging. The disk, which becomes overloaded by straw accumulation in its front, will not be able to appropriately cut the straw and only passes over it; the straw, not cut, hinders furrow opening by the tool located just behind the disks. The result is a poor work quality once work depth (deposition of fertilizers and seeds) is not maintained and straw coverage remains uneven, what allows weed emergence and hampers later cultivation operations. Therefore, the toothed cutting disk, which required lower torque in comparison with the smooth one, may be considered more effective, as it produces little straw movement and reduces plugging during work.

The disk required power is a product of the traction force (HF) and set displacement speed. The cultivator with two ranks (four disks and four chiseling shanks) worked at $6.2 \mathrm{Km} . \mathrm{h}^{-1}$. Therefore, the required power by each smooth disk was $1.69 \mathrm{~kW}$ and, for each toothed one, 0.93 $\mathrm{kW}$ (Table 1). There was a difference of $0.76 \mathrm{~kW}$ in the demanded power, about $1 \mathrm{hp}$, in favor of the toothed disk, what represents a reduction around $2 \mathrm{hp}$ in the effective power of the tractor drawbar for each cultivated sugarcane line. On the other hand, energy demand for each cutting disk may be determined from the required power and field capacity. Considering $1.5 \mathrm{~m}$ spacing among planting lines, the energy demand obtained for each sugarcane line (two disks) was $3.14 \mathrm{kWh} . \mathrm{ha}^{-1}$ when the smooth disk was used, and $1.73 \mathrm{kWh} \cdot \mathrm{ha}^{-1}$ (Table 1) for the toothed one, what represents a reduction of $1.41 \mathrm{kWh} . \mathrm{ha}^{-1}$ in favor of the toothed disk only during straw cutting. When these values are compared with those found by BORTOLOTTO et al. (2006), who worked with a seederfertilizer machine fitted with either a smooth disk of 15 " diameter for plant coverage cutting, furrow fertilizer with shanks, or furrow seeder with double phase disks of 13 " $\mathrm{x} 15$ " diameter under no tillage, a much superior value was observed, reaching the mean of $14.80 \mathrm{kWh} \mathrm{ha}^{-1}$. This difference occurs because, in this study, demand comes only from the disks and not from the whole set.

In the second stage, the sugarcane third harvesting was evaluated; treatment effects on the agroindustrial variables brix, pol, fiber, and ATR were not found, which presented mean values of $20.46 \%, 17.93 \%, 11.29 \%$, and $153.83 \mathrm{~kg} \mathrm{Mg}^{-1}$, respectively. Very close values were observed among treatments as well as low coefficients of variation. Treatments did not influence the sugarcane maturation stage as, at the harvest time, sugar and fiber contents were equal. Values of brix, pol, ATR, and fiber were similar to those obtained by TASSO JUNIOR et al. (2007).

Pol results resembled those described by OTTO et al. (2010), who did not find differences among potassium doses (from 100 to $200 \mathrm{Kg} \mathrm{ha}^{-1}$ ) and application forms (one or two topdressings). As those authors obtained similar values of agroindustrial variables for all treatments, it is possible to infer that there was no restriction to potassium use regardless the application form; according to CAMILOTTI et al. (2006), if there were differences in this nutrient availability, treatments with greater availability could present higher synthesis intensity and saccharose accumulation.

Analysis of the agronomic variables culm, alcohol, and sugar yields, indicated a significant effect among treatments as it is shown in Table 2. A similar behavior of all those variables was verified, but culm yield directly influenced the other results. Comparisons among culm yields evidenced that the treatment practiced by the Mill, with no soil chiseling and total area fertilization (ChA.DA-TA), as well as the control that did not have any fertilization or mechanical interference, were the only ones that differed from the others. These treatments presented a $17.60 \%$ inferior culm 
yield than the others, resulting in a loss of $24.47 \mathrm{Mg} \mathrm{ha}^{-1}$. The treatments Ch.TD-PL, Ch.TD-If, Ch.SD-PL, and Ch.SD-If, which included soil chiseling, showed similar culm yields to ChA.DA-PL that did not receive soil chiseling and fertilizer was deposited on planting lines.

TABLE 2. Sugarcane agronomic variables, with or without soil chiseling, and different fertilizer deposition forms.

\begin{tabular}{lccc}
\hline Treatment & $\begin{array}{c}\text { Culm Yield } \\
\left(\mathrm{Mg} \mathrm{ha}^{-1}\right)\end{array}$ & $\begin{array}{c}\text { Agronomic Variables } \\
\text { Alcohol Yield } \\
\left(\mathrm{m}^{3} \mathrm{ha}^{-1}\right)\end{array}$ & $\begin{array}{c}\text { Sugar Yield } \\
\left(\mathrm{Mg} \mathrm{ha}^{-1}\right)\end{array}$ \\
\hline Ch.TD-PL & $147.38 \mathrm{a}$ & $22.24 \mathrm{a}$ & $15.91 \mathrm{a}$ \\
Ch.TD-If & $141.43 \mathrm{a}$ & $21.15 \mathrm{ab}$ & $15.19 \mathrm{a}$ \\
Ch.SD-PL & $131.47 \mathrm{ab}$ & $20.51 \mathrm{abc}$ & $14.57 \mathrm{ab}$ \\
Ch.SD-If & $138.81 \mathrm{a}$ & $21.16 \mathrm{ab}$ & $15.15 \mathrm{a}$ \\
ChA.DA-PL & $136.02 \mathrm{a}$ & $20.83 \mathrm{abc}$ & $14.90 \mathrm{~b}$ \\
ChA.DA-TA & $114.55 \mathrm{~b}$ & $17.71 \mathrm{c}$ & $12.79 \mathrm{~b}$ \\
Control & $117.41 \mathrm{~b}$ & $18.17 \mathrm{bc}$ & $12.93 \mathrm{~b}$ \\
\hline Mean & 132.03 & 20.25 & 14.49 \\
CV $(\%)$ & 7.30 & 7.80 & 7.43 \\
\hline
\end{tabular}

${ }^{1}$ Values followed by the same letter in the column do not differ from each other by the Tukey test at 0.05 probability level.

Culm yield differences found among treatments, for fertilizer deposition on planting lines or in total area, probably occurred because, during broadcast fertilization, there is fertilizer dispersion on the straw, resulting in greater nitrogen losses. Results obtained by COSTA et al. (2003) indicated that the mixed application of urea and ammonium sulfate on straw, not on soil surface, favored $\mathrm{N}$ $\mathrm{NH}_{3}$ volatilization; furthermore, that lower sugarcane yields were derived from treatments that had greater $\mathrm{N}^{-\mathrm{NH}_{3}}$ losses. As a means of reducing losses by volatilization of nitrogen sources applied in sugarcane crops, WILLCOX (1990) recommends the nitrogen fertilizer incorporation in the soil, what was testified by this study once treatments that had localized fertilizer applications presented the greatest yields.

Soil chiseling did not cause any increment in culm yield, but when it was associated with localized fertilizer deposition, resulted in higher sugar yield per hectare, reaching the mean of 15.2 $\mathrm{Mg} \mathrm{ha}^{-1}$, against $13.8 \mathrm{Mg} \mathrm{ha}^{-1}$ from no chiseling. Results of alcohol yield followed the same sugar yield pattern, but less clearly, with only minor variations. Alcohol and sugar yields evidenced the soil chiseling positive effect on sugarcane commercial crops. Soil chiseling, associated with localized fertilizer deposition in years of uneven rainfall, may minimize crop yield losses in comparison with fertilizer application in total area, without chiseling.

Treatments that had fertilizer deposition on planting lines, without chiseling, did not show any significant difference in comparison with treatments that received the fertilizer incorporated into chiseling furrows. These results, probably, derived from the absence of soil compaction, once SPR was around $2.1 \mathrm{MPa}$ at 5 to $300 \mathrm{~mm}$ soil depth (Figure 1). As the rainfall regime in sugarcane regions have been undergoing changes in the last years and compacted soil layers are common in these regions, cultivation with localized fertilizer application and soil chiseling seem to be highly recommended. However, it is necessary to consider operation costs and sugarcane crop behavior along its productive life.

\section{CONCLUSIONS}

1- The toothed disk had greater capacity for sugarcane straw cutting as it required lower horizontal and vertical forces, lower torque, and presented higher energy efficiency;

2- Sugarcane agroindustrial variables were not influenced by soil chiseling and fertilizer deposition form; 
3- Localized fertilizer application, associated with soil chiseling, presented a better response regarding culm and sugar yield in comparison with broadcast application.

\section{ACKNOWLEDGEMENTS}

1- To Itamarati Mill, located in Nova Olímpia, Mato Grosso State, Brazil, for authorizing and supporting this study;

2- To Sindalcool-MT, for financial support to this project;

3- To Semeato Agricultural Machinery for providing the cultivator-fertilizer machine.

\section{REFERENCES}

ARATANI, R. G.; MARIA I. C.; CASTRO, O. M.; PECHE FILHO, A.; DUARTE A.;

KANTHACK, P. R. A. D. Desempenho de semeadoras-adubadoras de soja em Latossolo Vermelho muito argiloso com palha intacta de milho. Revista Brasileira de Engenharia Agrícola e Ambiental, Campina Grande, v.10, n.2, p.517-522, 2006.

BIANCHINI, A.; MAGALHÃES, P.S.G. Evaluation of coulters for cutting sugar cane residue in a soil Bin. Biosystems Engineering, London, v. 100, p. 370-375, 2008.

BORTOLOTTO, V.C.; NETO, R.P.; BORTOLOTTO, M.C. Demanda energética de uma semeadora-adubadora para soja sob diferentes velocidades de deslocamento e coberturas do solo. Engenharia Agrícola, Jaboticabal, v.26, n.1, p.122-130. 2006.

CAMILOTTI, F.; ANDRIOLI, I.; MARQUES, M.O.; SILVA, A.R.; TASSO JUNIOR, L.C.;NOBILE, F.O. NOGUEIRA, G.A.; PRATI, F. Produtividade e qualidade agroindustrial da canade-açúcar cultivada com lodo de esgoto, vinhaça e adubos minerais. STAB-Açúcar, Álcool eSubprodutos, Piracicaba, v.24, n.3, p.32-35, 2006.

CARVAlHO, L. A.; MEURER, I., SILVA Jr., C. A.; K. M. V. CAVALIERI ; C. F. B. SANTOS. Dependência espacial dos atributos físicos de três classes de solos cultivados com cana-de-açúcar sob colheita mecanizada. Revista Brasileira de Engenharia Agrícola e Ambiental, Campina Grande, v.15, n.9, p.940-949, 2011.

CHOI, C. H.; ERBACH, D. C. Cornstalk residue shearing by rolling coulters. Transactions of the $A S A E$, St. Joseph, v. 29, n. 6, p. 1530-1535, 1986.

CONSECANA. Manual de instruções. 5. ed. Piracicaba, 2006. 200p.

COSTA, M. C. G.; VITTI, G. C.; CANTARELLA, H. Volatilização de N-NH 3 de fontes nitrogenadas em cana-de-açúcar colhida sem despalha a fogo. Revista Brasileira de Ciência do Solo, Viçosa, MG, v.27, n.4, p.631-637, 2003.

FRANCO, H. C. J.; TRIVELIN, P. C. O.; FARONI, C. E.; VITTI, A. C.; OTTO, R. Aproveitamento pela cana-de-açúcar da adubação nitrogenada de plantio. Revista Brasileira de Ciência do Solo, Viçosa, MG, v. 32, p. 2763-2770, 2008, Número especial.

MAGALHÃES, P.S.G; BIANCHINI, A; BRAUNBECK, O.A. Simulated and Experimental Analyses of a Toothed Rolling Coulter for Cutting Crop Residues. Biosystems Engineering, London, v.96, n.2, p.193-200. 2007.

MION, R. L.; BENEZ, S. H. Esforços em ferramentas rompedoras de solo de semeadoras de plantio direto. Ciência e Agrotecnologia, Lavras, v. 32, n. 5, p. 1594-1600, 2008.

OTTO, R.; VITTI, G.C.; LUZ, P.H.C. Manejo da adubação potássica na cultura da cana-de-açúcar. Revista Brasileira de Ciência do Solo, Viçosa, MG, v.34, n.4, p.1137-1145, 2010.

OTTO, R. Desenvolvimento radicular e produtividade da cana-de-açúcar relacionados à mineralização do $\mathrm{N}$ do solo e à adubação nitrogenada. 2012. Tese (Doutorado em Solos e Nutrição de Plantas) - Escola Superior de Agricultura Luiz de Queiroz, Universidade de São Paulo, 
Piracicaba, 2012. Disponível em: <http://www.teses.usp.br/teses/disponiveis/11/11140/tde23032012-171851/>. Acesso em: 2012-abr.-18.

PERES, J. G.; SOUZA, C. F.; LAVORENTI, N. A. Avaliação dos efeitos da cobertura de palha de cana-de-açúcar na umidade e na perda de água do solo. Engenharia Agrícola, Jaboticabal, v.30, n.5, p.875-886, 2010.

RAMÃO, F. P.; SCHNEIDER, I. E.; SHIKIDA, P. F. A. Padrão tecnológico no corte de cana-deaçúcar: um estudo de caso no Estado do Paraná. Revista de Economia Agrícola, São Paulo, v. 54, n. 1, p. 21-32, jan./jun. 2007.

RODRIGUES, E. B.; ABI SAAB, O. J. G. Avaliação técnico-econômica da colheita manual e mecanizada da cana-de-açúcar (Saccharum spp) na região de Bandeirantes - PR. Semina: Ciências Agrárias, Londrina, v. 28, n. 4, p. 581-588, 2007.

SANTOS, A.J.M; GAMERO, C.A.; BACKES, C.; SALOMÃO, L.C.; BICUDO, S.J. Desempenho de discos de corte de semeadora-adubadora em diferentes quantidades de cobertura vegetal. Revista Energia na Agricultura. Botucatu, v. 25, n.4, 17-30, 2010.

SEVERIANO, E. C.; OLIVEIRA, G. C.; DIAS JÚNIOR, M. S.; CASTRO, M. B.; OLIVEIRA, L. F. C.; COSTA, K. A. P. Compactação de solos cultivados com cana-de-açúcar: I - modelagem e quantificação da compactação adicional após as operações de colheita. Engenharia Agrícola, Jaboticabal, v.30, n.3, p.404-413, 2010.

SILVA, P. R. A.; BENEZ, S. H.; JASPER, S. P.; SEKI, A. S.; MASIERO, F. C.; N. B. RIQUETTI. Semeadora-adubadora: mecanismos de corte de palha e cargas verticais aplicadas. Revista Brasileira de Engenhara Agrícola e Ambiental, Campina Grande, v.16, n.12, p.1367-1373, 2012.

TASSO JUNIOR, L.C.; MARQUES, M.O.; FRANCO, A.; NOGUEIRA, G.A.; NOBILE, F.O.; CAMILOTTI, F.; SILVA, A.R. Produtividade e qualidade de cana-de-açúcar cultivada em solo tratado com lodo de esgoto, vinhaça e adubos minerais. Engenharia Agrícola, Jaboticabal, v.27, n.1, p.276-283, 2007.

TOMASINI, B.A.; VITORINO, A.C.T.; GARBIATE, M.V.; SOUZA, C.M.A.; SOBRINHO, T.A. Infiltração de água no solo em áreas cultivadas com cana-de-açúcar sob diferentes sistemas de colheita e modelos de ajustes de equações de infiltração. Engenharia Agrícola, Jaboticabal, v.30, n.6, p.1060-1070, 2010.

WILLCOX, T. Proserpine growers develop new fertilizers applicators. Journal BSES Bulletin, n.29, p.20-21, 1990. 